\title{
ANALISA KELAYAKAN ETANOL KADAR RENDAH SEBAGAI BAHAN BAKAR PADA KOMPOR BERGRAVITASI
}

\author{
Ahmad Wardi Salim, I Made Mara, Yesung Allo Padang \\ Jurusan Teknik Mesin Fakultas Teknik Universitas Mataram \\ Jl. Majapahit No.62 Mataram Nusa Tenggara Barat Kode Pos: 83125 \\ Telp. (0370) 636087; Fax (0370) 636087, Email; made.mara@ymail.com
}

\begin{abstract}
Low grade alcohol is energy that can be renewed. when compared to kerosene and LPG, bioethanol stove is non explossive, does not require a large pressure and easy to manufacture.

This study to determine the effect of the height and length of heating coil burner water heating time, preparation time and fuel consumption. The principle of low grade of ethanol stove is used the position of the fuel tank height and speed up the process of evaporation. Variations used in this study is the length of the heating coil burner that is $55 \mathrm{~cm}, 75 \mathrm{~cm}, 95 \mathrm{~cm}$, and height is given by $1.5 \mathrm{~m}, 1.75 \mathrm{~m}$, and $2 m$.

The results indicate that the use water heating fastest time obtained at $2 m$ height variation with of $95 \mathrm{~cm}$ burner heating coil of 790 seconds. At the time of preparation reduction obtained at the optimal height variation of 1.5 mand lenghth $95 \mathrm{~cm}$ of burner heating coils is 328 sekonds. The lowest fuel consumption obtained when using length variation burner heating coil $55 \mathrm{~cm}$ and a height of $1.5 \mathrm{~m}$ at $0.132 \mathrm{ml} / \mathrm{sec}$.
\end{abstract}

Key words: Ethanol, low grade, stove, performance

\section{Pendahuluan}

Sehubungan dengan meningkatnya populasi manusia dan meningkatnya taraf hidup masyarakat, maka kebutuhan bahan bakar juga semakin meningkat. Berbagai jenis bahan bakar telah digunakan oleh manusia seperti minyak bumi, gas alam, dan batubara. Sebagian besar rumah tangga pedesaan yang terdapat di Indonesia dan di negara-negara berkembang lainnya memasak masih menggunakan kompor dengan bahan bakar kayu (biomass). Hal ini dapat menyebabkan kerugian diantaranya, Selain dapat menimbulkan polusi lingkungan, kompor ini juga tidak baik bagi kesehatan manusia. Akibat pembakaran bahan bakar padat berisi polutan yang kompleks, Sehingga berbahaya ketika dibakar pada kompor yang dirancang dengan tidak baik dan pada tempat yang tidak mempunyai sirkulasi udara. Menurut World Health Organisation (WHO), lebih dari 1,6 juta kematian dunia timbul dari polusi udara dalam ruangan akibat penggunaan bahan bakar biomassa (ITDG, 2004).

Hampir 90\% masyarakat tergantung pada berbagai bentuk bahan bakar biomassa lainnya seperti kayu bakar, limbah pertanian, dan batubara, untuk memenuhi kebutuhan energi. ( $D$ 'Sa, et all, 2004). Oleh karena itu, untuk meningkatkan dan memenuhi taraf hidup manusia seperti sebagian besar orang, sangat penting untuk mengembangkan energi alternatif yang baik dan berkelanjutan guna memenuhi kebutuhan energi.

Ketersediaan biaya bahan bakar untuk memasak seperti bahan bakar cair dan gas semakin jauh dari jangkauan masyarakat. Selain itu, bahan bakar ini tidak terbarukan dan hanya merupakan solusi jangka pendek. Untuk mengatasi krisis bahan bakar memasak maka energi alternative terbarukan harus dipromosikan yaitu bahan bakar alkohol.

Dalam penelitian kompor bioetanol yang berada di masyarakat sekarang ini hanya mampu menyala dengan kadar alkohol tinggi, dimana harga bioetanol dengan kadar alkohol tinggi memiliki harga yang lumayan mahal untuk tiap liternya. Maka timbullah suatu permasalahan, Diantaranya kompor tidak mau menyala dengan kadar alkohol yang rendah.

Jika kompor bioetanol menggunakan kadar alkohol kurang dari $60 \%$ kebanyakan kompor bioetanol akan cepat padam, karena air pada kandungan bioetanol tidak bisa menguap keseluruhan sehingga menumpuk dan mengakibatkan kompor tidak mau menyala. Bioetanol sekarang ini sudah dapat diproduksi pada sektor home industri, dimana masyarakat sekarang semakin maju dalam pembuatan bioetanol dengan kadar alkohol rendah berkisar 
antara 40\%-60\%. Mereka dapat melakukan produksi sendiri dengan cara fermentasi dan penyulingan dari bahan umbi-umbian dan sejenisnya, tapi kebanyakan dari mereka kesulitan dalam memproduksi dengan kadar 90\%. Yang mana alkohol kadar 90\% kebanyakan diproduksi pada perusahaan besar, sehingga masyarakat hanya memproduksi dalam skala sedikit. Oleh karena itu, peneliti ingin mencoba menguji kualitas alkohol dengan konsentrasi rendah sebagai bahan bakar skala rumah tangga. (Krismiadi 2011).

\section{Landasan Teori}

Pemanfaatan kompor bertekanan yang sudah tersedia di masyarakat menggunakan bioetanol masih mengalami kendala, Khususnya deposit atau penumpukan kerak sisa pembakaran pada nozzle yang menyebabkan penyumbatan sehingga proses pembakaran tidak berjalan dengan lancar dan warna apinya merah. Kompor bertekanan rancangan Universitas Hohenheim Jerman memiliki spuyer dan bagian pendukungnya yang lebih baik, terbukti dengan nyala api yang kebiruan tanpa jelaga, yang berarti pembakarannya terjadi hampir sempurna. Hal ini disebabkan terutama prinsip rancangan yang berbeda, yaitu dengan membuat minyak terevaporasi lebih dahulu, baru kemudian keluar dari nozzle dan dibakar. Sedangkan kompor tekanan yang umumnya digunakan pedagang di pinggir jalan, minyak yang keluar dari nozzle dan terbakar masih berupa cairan lembut, sehingga pembakarannya kurang sempurna dibandingkan dengan uap minyak yang terbakar. (Muhlbauer 1998 dalam Stumpf, 2002).

Memodifikasi kompor tekan yang awalnya untuk minyak tanah. Hasilnya menunjukkan bahwa untuk penyalaan awal memang lebih lama dibandingkan jika menggunakan minyak tanah. Titik bakar (fuel ignition point) dari bahan bakar bioetanol yang lebih tinggi dibandingkan minyak tanah atau solar menyebabkan perlunya pemanasan awal pada penggunaan kompor tekan tersebut. Hal ini sama seperti halnya pemakaian lampu petromak. Penggunaan kompor tekan dengan bahan bakar minyak tanah juga masih memerlukan pemanasan awal, hanya waktu pemanasannya lebih cepat karena titik bakar minyak tanah lebih rendah dibandingkan bioetanol. (Reksowardojo 2006.

Enau atau aren (Arenga pinnata, suku Arecaceae) adalah palma yang merupakan tanaman serbaguna. Tumbuhan ini dikenal dengan berbagai nama seperti nau, hanau, biluluk, kabung, juk atau ijuk ( aneka nama lokal di Nusa Tenggara ); moka, moke, tuwa, tuwak, dan lain - lain. Pohon enau menghasilkan banyak hal, yang menjadikanya populer sebagai tanaman yang serbaguna, terutama sebagai penghasil gula. Nira Aren di beberapa daerah selain sebagai bahan pemanis, melalui proses fermentasi, Nira diubah menjadi minuman beralkohol yang dikenal dengan nama tuak. Alkohol yang dihasilkan secara ilmiah dikenal dengan nama Etanol Nira. Etanol Nira dapat diubah menjadi bioetanol. Bioetanol merupakan bahan bakar dari minyak nabati dengan bantuan fermentasi oleh bakteri ragi (Saccharomyces cereviseae) dimana kandungan gula (sukrosa) pada nira dikonversi menjadi glukosa kemudian menjadi etanol yang produknya disebut sebagai bioethanol. Adapun nira yang biasa dideras dari berbagai jenis palma (Arenga pinnata, Borassus flabellifer, Cocos Nucifera and Nypa Fruticans) kandungan total gulanya berkisar 10-20\%. Apabila dibudidayakan dengan baik, akan sangat potensial dimanfaatkan untuk pembuatan ethanol, Karena produktifitasnya bisa mencapai 20 ton gula per hektar per tahun ( Akuba, et al, 2004).

Etanol disebut juga etil-alkohol atau alkohol saja, adalah alkohol yang paling sering digunakan dalam kehidupan sehari-hari, hal ini disebabkan karena memang etanol yang digunakan sebagai bahan dasar pada minuman, bukan metanol, atau grup alkohol lainnya. Sedangkan bioetanol adalah etanol (alkohol yang paling dikenal masyarakat) yang dibuat dengan fermentasi yang membutuhkan faktor biologis untuk prosesnya.( Indartono , 2004).

\section{Metode penelitian}

Dalam penelitian ini dilakukan dengan menggunakan metode :

1. Eksperimen yaitu dengan menyelidiki hubungan sebab akibat dari kondisi perlakuan dengan alat peraga.

2. Study literatur (library research), yaitu dengan cara mempelajari literatur-literatur yang berkaitan dengan masalah yang dibatasi.

Alat berupa :

1. Tangki bahan bakar yang digunakan dari botol minuman plastik kemasan 1 liter.

2. Pipa tembaga $2 \mathrm{~mm}$, digunakan sebagai koil pemanasan burner.

3. Roll tip meter, digunakan untuk mengetahui ketinggian yang diberikan. 
4. Termometer, digunakan untuk mengukur suhu pada saat memanaskan air.

5. Stopwatch, digunakan untuk menghitung waktu pemakaian bahan bakar etanol dan lama waktu yang dibutuhkan untuk pemanasan awal hingga kompor menyala.

6. Gelas ukur, digunakan untuk mengukur jumlah bahan bakar alkohol yang akan digunakan.

7. Suntikan speed, digunakan untuk menambahkan volume bahan bakar ke dalam tabung bahan bakar.

8. Corong, digunakan untuk memasukkan bahan bakar alkohol ke dalam tabung kompor.

9. Panci, digunakan untuk memanaskan air.

10.Alkohol meter, digunakan untuk mengukur kadar alkohol bahan bakar.

Bahan

1. Alkohol kosentrasi $50 \%$

2. Air

\section{Hasil dan Pembahasan}

Setelah dilakukan penelitian pengaruh penggunaan ketinggian posisi bahan bakar dan panjang koil pemanasan burner terhadap waktu yang dibutuhkan untuk pemanasan awal hingga kompor menyala (preparation time), maka didapatkan data rata-rata sebagai berikut:

Tabel 4.1 Rerata preparation time (detik)

\begin{tabular}{|c|c|c|c|}
\hline \multirow{2}{*}{$\begin{array}{l}\text { Panjang Koil } \\
\text { Pemanasan } \\
\text { burner (cm) }\end{array}$} & \multicolumn{3}{|c|}{$\begin{array}{c}\text { Preparation Time } \\
\text { (detik) }\end{array}$} \\
\cline { 2 - 4 } & $\begin{array}{c}\text { Ketinggian } \\
1.5 \mathrm{~m}\end{array}$ & $\begin{array}{c}\text { Ketinggian } \\
1.75 \mathrm{~m}\end{array}$ & $\begin{array}{c}\text { Ketinggian } \\
2 \mathrm{~m}\end{array}$ \\
\hline 55 & 348 & 350 & 352 \\
\hline 75 & 338 & 347 & 350 \\
\hline 95 & 328 & 343 & 345 \\
\hline
\end{tabular}

Dari pengujian analisa statistik anova two factor with replication seperti pada tabel 4.2 dapat diketahui bahwa panjang koil pemanasan burner dan ketinggian posisi bahan bakar berpengaruh secara signifikan terhadap preparation time, dimana $F_{\text {hitung }}(F)$ dari pengaruh panjang koil dan ketinggian lebih besar dari pada $F_{\text {tabel }}$ ( $F$ crit) pada taraf signifikan $5 \%(3,55)$, Interaksi antara penggunaan panjang koil dan ketinggian posisi bahan bakar berpengaruh nyata terhadap preparation time dimana $F_{\text {hitung }}$ lebih besar dari pada $F_{\text {tabel }}(\mathrm{F}$ crit) pada taraf signifikan 5\% $(2,92)$.
Tabel 4.2 Analisa Ragam Preparation Time

\begin{tabular}{|l|l|l|l|l|l|}
\hline Source of Var & SS & $D f$ & $M S$ & $F$ & F crit 5\% \\
\hline Panjang Koil & 592,5185 & 2 & 296,2593 & 37,20465 & 3,554557 \\
\hline Ketinggian & 570,2963 & 2 & 285,1481 & 35,8093 & 3,554557 \\
\hline Interaction & 166,1481 & 4 & 41,53704 & 5,216279 & 2,927744 \\
\hline Within & 143,3333 & 18 & 7,962963 & & \\
\hline Total & 1472,296 & 26 & & & \\
\hline
\end{tabular}

\section{Grafik Preparation Time fungsi panjang koil pemanasan burner dan ketinggian}

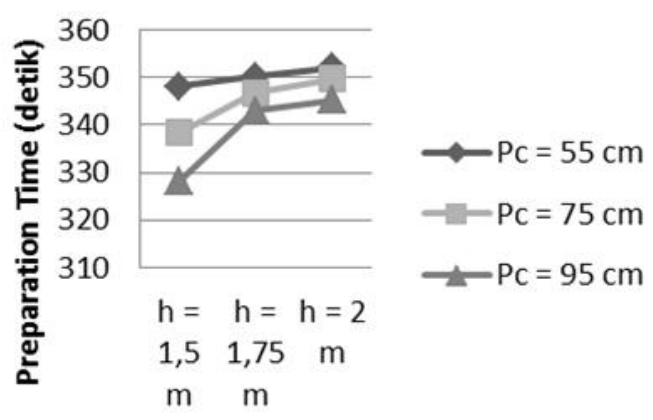

Gambar 4.1 Grafik Preparation Time fungsi panjang koil pemanasan burner

Dari gambar 4.1 tampak bahwa semakin tinggi posisi bahan bakar, maka preparation time meningkat. Secara teoritis dapat dijelaskan bahwa, peningkatan ini disebabkan karena semakin tinggi posisi bahan bakar maka jumlah bahan bakar yang akan dievaporasi semakin banyak, sehingga waktu yang dibutuhkan untuk merubah bahan bakar cair menjadi uap akan semakin lama, maka waktu yang dibutuhkan semakin lama.

Sedangkan semakin panjang koil pemanasan maka prepation time menurun. Hal ini disebabkan karena semakin panjang koil pemanasan burner, maka proses evaporasi bahan bakar akan semakin cepat karena luasan aliran bahan bakar yang dipanaskan semakin besar, sehingga waktu yang dibutuhkan bahan bakar menguap dan terbakar semakin cepat. Apabila membandingkan penurunan preparation time antara panjang koil pemanasan burner yang ada, dapat di lihat bahwa dengan menggunakan panjang koil $95 \mathrm{~cm}$ terjadi penurunan nilai preparation time optimal dibandingkan dengan penggunaan panjang koil 55 dan $75 \mathrm{~cm}$ pada ketinggian yang sama, hal ini disebabkan karena pada saat penggunaan panjang koil $95 \mathrm{~cm}$, bahan bakar yang mengalir menuju burner akan cepat menguap karena 
luasan aliran bahan bakar yang dipanaskan semakin besar. Sedangkan pada penggunaan panjang koil 55 dan $75 \mathrm{~cm}$, bahan bakar membutuhkan waktu yang lama untuk menguap dan terbakar karena luasan aliran bahan bakar yang dipanaskan terlalu kecil. Preparation time optimal didapat pada penggunaan panjang koil $95 \mathrm{~cm}$ dengan ketinggian $1.5 \mathrm{~m}$ sebesar 328 detik. Jika dibandingkan dengan menggunakan panjang koil $55 \mathrm{~cm}$ pada ketinggian $1.5 \mathrm{~m}$ didapat penurunan preparation time sebesar 20 detik (348 - 328 detik ).

Tabel 4.3 Rerata waktu pemanasan air hingga suhu $80{ }^{\circ} \mathrm{C}$ (detik)

\begin{tabular}{|c|c|c|c|}
\hline \multirow{2}{*}{$\begin{array}{l}\text { Panjang Koil } \\
\text { Pemanasan } \\
\text { burner }(\mathrm{cm})\end{array}$} & \multicolumn{3}{|c|}{ Waktu Pemanasan Air (detik) } \\
\hline & $\begin{array}{c}\text { Ketinggian } \\
1.5 \mathrm{~m}\end{array}$ & $\begin{array}{c}\text { Ketinggian } \\
1.75\end{array}$ & $\begin{array}{c}\text { Ketinggian } \\
2 \mathrm{~m}\end{array}$ \\
\hline 55 & 801 & 799 & 797 \\
\hline 75 & 799 & 797 & 794 \\
\hline 95 & 796 & 793 & 790 \\
\hline
\end{tabular}

Tabel 4.4 Analisa Ragam Waktu pemanasan 1 liter air hingga suhu $80{ }^{\circ} \mathrm{C}$

\begin{tabular}{|l|l|l|l|l|l|}
\hline $\begin{array}{c}\text { Source of } \\
\text { Var }\end{array}$ & \multicolumn{1}{|c|}{ SS } & \multicolumn{1}{c|}{ Df } & \multicolumn{1}{c|}{$M S$} & \multicolumn{1}{c|}{$F$} & F crit5\% \\
\hline Panjang Koil & 159,8956 & 2 & 79,94778 & 8,751632 & 3,554557 \\
\hline ketinggian & 119,12 & 2 & 59,56 & 6,519846 & 3,554557 \\
\hline Interaction & 0,87778 & 4 & 0,219444 & 0,024022 & 2,927744 \\
\hline Within & 164,4333 & 18 & 9,135185 & & \\
\hline Total & 444,3267 & 26 & & & \\
\hline
\end{tabular}

Dari pengujian analisa statistik anova two factor with replication seperti pada tabel 4.4 dapat diketahui bahwa panjang koil pemanasan burner, ketinggian posisi bahan bakar berpengaruh nyata terhadap waktu pemanasan 1 liter air hingga suhu $80{ }^{\circ} \mathrm{C}$, dimana $F_{\text {hitung }}(F)$ lebih besar dari pada $F_{\text {tabel }}(F$ crit) pada taraf signifikan $5 \%(3,55)$ dari pengaruh panjang koil dan Ketinggian. Sedangkan interaksi antara penggunaan ketinggian dan panjang koil pemanasan burner, tidak berpengaruh nyata terhadap waktu pemanasan air, dimana $F_{\text {hitung }}$ (F) lebih kecil dari pada $F_{\text {tabel }}(F$ crit) pada taraf signifikan 5\% (2,92).

Berikut yang dihasilkan dari tabel rerata waktu pemanasan 1 liter air.

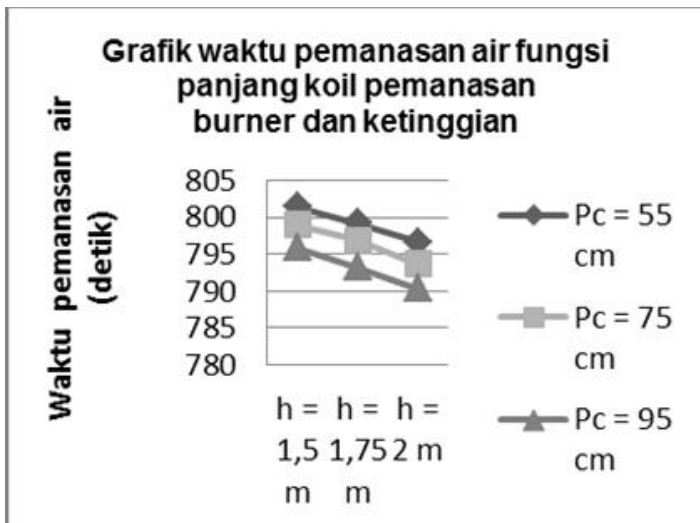

Gambar 4.2 Grafik waktu pemanasan 1 liter air fungsi panjang koil pemanasan burner dan variasi ketinggian.

Dari gambar 4.2 tampak bahwa semakin panjang koil pemanasan burner, maka diiringi dengan menurunnya waktu pemanasan 1 liter air. Secara teoritis dapat dijelaskan bahwa penurunan ini disebabkan karena semakin panjang koil pemanasan maka bahan bakar akan mudah terevaporasi karena luasan aliran bahan bakar yang dipanaskan semikin besar sehingga waktu yang dibutuhkan bahan bakar menguap dan terbakar semakin cepat. Pada penggunaan koil $95 \mathrm{~cm}$ terjadi penurunan optimal waktu pemanasan air secara nyata, hal ini disebabkan karena pada saat penggunaan koil $95 \mathrm{~cm}$, bahan bakar yang mengalir menuju burner akan cepat menguap karena luasann aliran bahan bakar yang dipanaskan semakin besar maka koil akan terus dapat menguapkan bahan bakar, sehingga energi yang keluar dari hasil pembakaran semakin besar, dan waktu yang dibutuhkan untuk memanaskan air hingga suhu $80^{\circ} \mathrm{C}$ semakin cepat. Sedangkan penggunaan panjang koil $55 \mathrm{~cm}$ dan $75 \mathrm{~cm}$ terjadi penurunan waktu pemanasan air akan tetapi tidak penurunan secara optimal jika dibandingkan dengan penggunaan koil $95 \mathrm{~cm}$ dengan ketinggian yang sama, karena panjang koil $55 \mathrm{~cm}$ dan $75 \mathrm{~cm}$ bahan bakar membutuhkan waktu yang lama untuk menguap dan terbakar karena luasan aliran bahan bakar yang dipanaskan terlalu kecil.

Sedangkan semakin tinggi posisi bahan bakar, maka jumlah bahan bakar yang telah menguap dan terbakar semakin banyak, sehingga energi pembakaran yang dihasilkan lebih besar sehingga waktu pemanasan air semakin cepat.

Apabila kita membandingkan penurunan nilai waktu pemanasan air yang terjadi pada tiap panjang koil pemanasan burner yang ada, dapat 
kita lihat bahwa pada saat penggunaan panjang koil $95 \mathrm{~cm}$, waktu pemanasan 1 liter air pada ketinggian $2 \mathrm{~m}$ terjadi penurunan sebesar 7 detik (797-790 detik). jika dibandingkan dengan menggunakan panjang koil $55 \mathrm{~cm}$ pada ketinggian yang sama, sedangkan untuk nilai waktu pemanasan air 1 liter optimal terdapat di penggunaan panjang koil $95 \mathrm{~cm}$ dan ketinggian $2 \mathrm{~m}$ sebesar 790 detik.

Pengaruh penggunaan Ketinggian dan panjang koil pemanasan burner terhadap konsumsi bahan bakar.

Tabel 4.5 Rerata Konsumsi Bahan Bakar (ml/detik)

\begin{tabular}{|c|c|c|c|}
\hline \multirow{2}{*}{$\begin{array}{l}\text { Panjang Koil } \\
\text { Pemanasan } \\
\text { burner (cm) }\end{array}$} & \multicolumn{3}{|c|}{$\begin{array}{l}\text { Konsumsi Bahan Bakar } \\
\text { (ml/detik) }\end{array}$} \\
\hline & $\begin{array}{c}\text { Ketinggian } \\
1.5 \mathrm{~m}\end{array}$ & $\begin{array}{c}\text { Ketinggiar } \\
1.75 \mathrm{~m}\end{array}$ & $\begin{array}{l}\text { Ketinggian } \\
2 \mathrm{~m}\end{array}$ \\
\hline 55 & 0,132 & 0,135 & 0,140 \\
\hline 75 & 0,132 & 0,138 & 0,143 \\
\hline 95 & 0,136 & 0,142 & 0,145 \\
\hline
\end{tabular}

Tabel 4.6. Analisa Ragam Nilai Fuel Consumption (FC)

\begin{tabular}{|l|c|c|c|c|c|}
\hline \multicolumn{1}{|c|}{$\begin{array}{c}\text { Source of } \\
\text { Var }\end{array}$} & $S S$ & $d f$ & $M S$ & $F$ & $F$ crit 5\% \\
\hline Panjang Koil & 0,000118 & 2 & $5,91 \mathrm{E}-05$ & 4,269943 & 3,554557 \\
\hline Ketinggian & 0,000387 & 2 & 0,000194 & 14,0037 & 3,554557 \\
\hline Interaction & $1,21 \mathrm{E}-05$ & 4 & $3,02 \mathrm{E}-06$ & 0,217961 & 2,927744 \\
\hline Within & 0,000249 & 18 & $1,38 \mathrm{E}-05$ & & \\
\hline Total & 0,000767 & 26 & & & \\
\hline
\end{tabular}

Dari pengujian analisa statistik anova two factor with replication seperti pada tabel 4.6 dapat diketahui bahwa panjang koil pemanasan burner berpengaruh nyata terhadap konsumsi bahan bakar, dimana $F_{\text {hitung }}(F)$ dari pengaruh panjang koil lebih besar dari pada $F_{\text {tabel }}(\mathrm{F}$ crit) pada taraf signifikan $5 \%(3,55)$ dan ketinggian posisi bahan bakar berpengaruh nyata terhadap konsumsi bahan bakar dimana $F_{\text {hitung }}(F)$ lebih besar dari pada $F_{\text {tabel }}(F$ crit). Jika semakin tinggi yang digunakan maka jumlah bahan bakar yang keluar melalui nosel akan semakin banyak pada taraf signifikan $5 \%(3,55)$.

Namun interaksi antara penggunaan ketinggian dan panjang koil pemanasan burner, tidak berpengaruh nyata terhadap fuel consumption dimana $F_{\text {hitung }}(F)$ lebih kecil dari pada $F_{\text {tabel }}(F c r i t)$ pada taraf signifikan 5\% $(2,92)$.

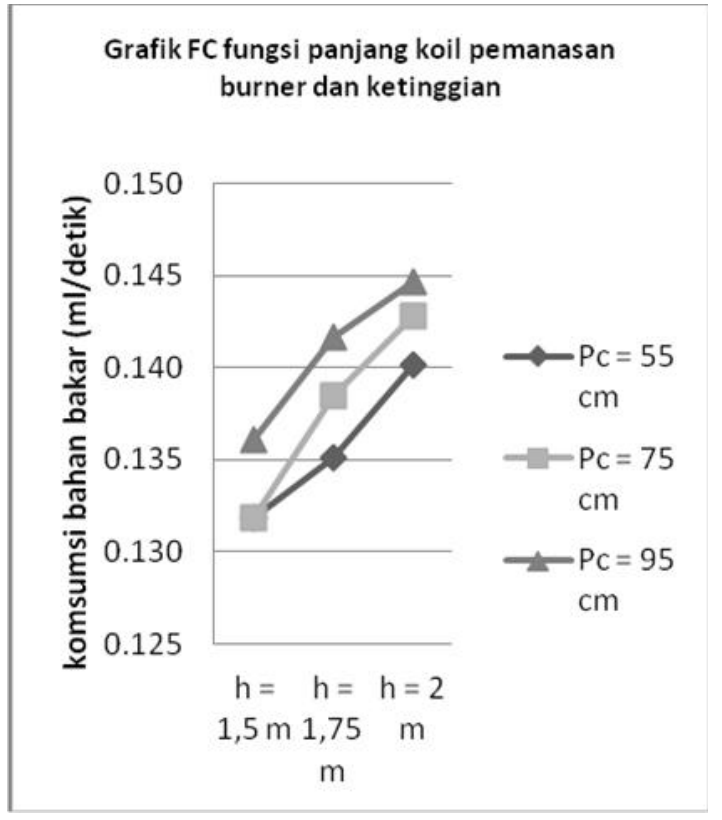

Gambar 4.3 Grafik FC fungsi panjang koil pemanasan burner dan variasi ketinggian.

Pada gambar 4.3 terlihat bahwa semakin tinggi posisi bahan bakar yang digunakan, maka diikuti pula oleh meningkatnya nilai konsumsi bahan bakar. Sedangkan berdasarkan analisa data statistik, ketinggian memberikan pengaruh yang signifikan terhadap kenaikan konsumsi bahan bakar pada taraf $5 \%$, karena semakin tinggi posisi bahan bakar jumlah bahan bakar yang menguap dan keluar melalui nosel akan semakin banyak, sehingga konsumsi bahan bakar akan semakin tinggi.

Apabila membandingkan peningkatan nilai komsumsi bahan bakar yang terjadi pada tiap panjang koil pemanasan burner yang ada dengan ketinggian $1,5 \mathrm{~m}$, dapat di lihat bahwa pada saat penggunaan panjang koil $95 \mathrm{~cm}$ waktu pemanasan 1 liter air pada ketinggian 1,5 $\mathrm{m}$ terjadi peningkatan nilai Fuel Consumption sebesar 0,004 ml/detik(0,136 - 0,132 ml/detik). Hal ini disebabkan karena semakin panjang koil pemanasan maka bahan bakar akan mudah menguap dan terbakar, sehingga energi dari hasil pembakaran semakin besar. Jika melihat pemakian bahan bakar yang optimal dari hemat pemakian bahan bakar didapat pada penggunaan panjang koil 55 dan $75 \mathrm{~cm}$, waktu pemanasan 1 liter air pada ketinggian $1,5 \mathrm{~m}$ sebesar 0,132 $\mathrm{ml} /$ detik. 


\section{Kesimpulan}

Dari rangkaian penelitian yang telah dilakukan dapat ditarik beberapa kesimpulan sebagai berikut :

1. Secara analisa statistik anova, penggunaan panjang koil pemanasan burner dan ketinggian posisi bahan bakar berpengaruh nyata terhadap preparation time pada taraf signifikan 5\%.

2. Preparation time optimal didapatkan pada penggunaan panjang koil $95 \mathrm{~cm}$ pada ketinggian $1.5 \mathrm{~m}$ sebesar 328 detik.

3. Secara analisa statistik anova, penggunaan panjang koil pemanasan burner dan ketinggian berpengaruh nyata terhadap penurunan waktu pemanasan air, sedangkan interaksi penggunaan panjang koil dan ketinggian tidak berpengaruh nyata pada taraf signifikan $5 \%$.

4. Waktu pemanasan 1 liter air terbaik (optimal) didapatkan pada penggunaan panjang koil $95 \mathrm{~cm}$ pada ketinggian $2 \mathrm{~m}$ sebesar 790 detik.

5. Secara analisa statistik anova, penggunaan panjang koil pemanasan burner dan ketinggian berpengaruh nyata terhadap penurunan Fuel Consumption, sedangkan interaksi penggunaan dan ketinggian, ketinggian tidak berpengaruh nyata pada taraf signifikan $5 \%$.

6. Fuel Consumption optimal didapatkan pada penggunaan panjang koil pemanasan burner $55 \mathrm{~cm}$ dan 75 ketinggian $1,5 \mathrm{~m}$ sebesar $0,132 \mathrm{ml} /$ detik jika dilihat dari hemat/irit pemakian bahan bakar (komsumsi bahan bakar).

\section{DAFTAR PUSTAKA}

Akuba, R.H.2004. Profil Aren. Pengembangan Tanaman Aren. Prosiding Seminar Nasional Aren. Tondano. Balai Penelitian Tanaman Kelapa dan Palma Lain. , 9 Juni.hlm.1-9.

Indartono, Y. 2005. Bioethanol, alternatif energi terbarukan: Kajian prestasi mesin dan implementasi di lapangan. Ånergi http://www.energi.lipi.go.id (diakses 20 november 2004).

Krismiadi 2011, Alkohol kadar rendah sebagai bahan bakar. Warta Penelitian dan pengembangan ruang bakar kompor tahun 2011.

Mara, I Made., Nuarsa. I Made, 2001, Diktat Motor Bakar, Mataram; Jurusan Teknik Mesin, Fakultas Teknik, Universitas Mataram.

Mühlbauer, W., A. Esper, E. Stumpf and R. Baumann. 1998. Plant Oil-based Cooking Stove - A Technology Update. Makalah dalam Workshop Rural Energy, Equity and Employment : Role of Atrophy Curcas. Harare, Zimbabwe, $13-15$ May 1998. Scientific and Industrial Research and Development Centre (SIRDC).

Reksowardojo,IK. 2005. Kompor Bio-Ethanol. Ilmu dan Teknologi. Koran Tempo 5 Desember 2005 : C6-C7.

Rajvanshi, Anil K., S M Patil and B. Mendoca. 2004. Development of Stove Running on Low Ethanol Concentration. NARI. Nov. 2004. India. 